\title{
RELATIONSHIP BETWEEN BANK OWNERSHIP CONCENTRATION ON CAPITAL ADEQUACY, LIQUIDITY, AND CAPITAL STABILITY IN THE LISTED BANKS IN TEHRAN STOCK EXCHANGE
}

\author{
M. R. Vatanparast* and H. Behtooie \\ Department of Accounting, Rasht branch, Islamic Azad University, Rasht, Iran
}

Published online: 15 May 2016

\begin{abstract}
In this study we explore the effects of ownership concentration on the risk-taking behavior of banks. Our analysis focuses on East Asian countries because these nations have successfully implemented the Basel standards and have demonstrated a high degree of regulatory convergence. For the period from 2005 to 2009, we analyzed the relation between ownership concentration and capital adequacy (Basel II) and find that an increase in ownership concentration by one standard deviation results in an improvement in capital adequacy by $32 \%$.

Motivated by public policy considerations, we analyze the impact of bank ownership structure as a governance mechanism on capital adequacy and liquidity in Asian banks. The results show that as ownership concentration rises, banks become well capitalized and more liquid. The impact is both statistically and economically significant. Our results complement recent findings reported by Peni and Vahamaa (2011) that corporate governance mechanisms are material factors in explaining banks' behavior and their market performance. Our results also support Vauhkonen's (2011) findings that market discipline manifested through ownership concentration significantly impacts banks' capital adequacy, liquidity, and capital stability
\end{abstract} Keywords: Basel II; bank ownership; capital adequacy; capital stability; financial crisis.

Author Correspondence, e-mail: hossein.behtooi@gmail.com

doi: http://dx.doi.org/10.4314/jfas.v8i3s.237 


\section{INTRODUCTION}

In this study, risk-taking by banks at a fundamental level by examining the impact of ownership concentration on capital adequacy and liquidity requirements of Basel II have been investigated. To understand the relationship between stability and concentration of ownership of capital, Basel II standards for capital stability in an experimental environment hypothetical example, apply to banks. According to the hypothesis, the fundamental question is this: if the stability of the Basel II standards during the period under study (92-1389) actually came into force, the stability of capital banks must be influenced by the concentration of ownership was?

\section{The concept of Basel}

The Basel Committee is the most active international organizations involved in the banking system. Basel Committee in response to a global necessity for cooperation in the fields of banking supervision, including monitoring and provide guidance and recommendations to encourage convergence in the application of standards and practices of banking supervision in the Member States and other non-member countries to ensure the health and safety Books it is effective to maintain continuity (Shahrokh, GH, June 1385).

\section{The fundamental concept of capital adequacy:}

Capital, an important element of the Bank's financial support will enable the bank to cope with economic problems have the ability to repay their debts. As well as the important role they play in the financial stability of banks and risk-taking incentives. Since that ensures the maintenance of reliable funding sources to reduce risk-taking investment banks is, therefore, one of the most important criteria to assess banks' capital adequacy ratio. This ratio is the first time in 1988 by the Basel Committee on banking was introduced. The Basel Committee is a set of minimum capital requirements for banks suggested that later became known as the Basel Accord (Hosseini, Ali 1385).

\section{The definition of capital adequacy}

Based capital divided capital adequacy ratio (as defined in the Regulations concerning basic capital) to total assets weighted by risk factors in terms of percent (according to the definition provided in Article 5 of this Regulation) is.

\section{Calculation of capital adequacy ratio}

Total items above the line and below the line that is based on the weighted risk factors, capital adequacy ratio will be in the denominator. Numerator, based on the criteria set forth in the "Regulations on basic capital" is calculated. Therefore: 
Capital adequacy ratio $=$ Capital base $/$ (items above the line (risk factor) + items below the line (FCR) (risk ratio)

\section{Basel I}

The advent of Basel I cannot repay the debt crisis return to Mexico in 1982.were not of major regional lies in Basel I is (Rosa maria lastva 2004).

\section{Basel II}

Basel 2 is a voluntary agreement between the authorities agreed to total bank is the majority of developing countries.be. The purpose of this agreement was to secure international financial system (Attarian, Amir, 1386).

Basel II in January 2001 with the publication of a design, major changes in the capital structure of the organization in which the "New Basel Capital Accord II» is called.

\section{Between Basel I and II}

\section{Basel I}

$>$ simple and easy

$>$ a pillar and minimum capital

$>$ the calculation of minimum capital requirements for credit risk and market risk since 1996 and lacks the operational risk

\section{Basel II}

$>$ difficult

$>$ has three pillars

$>$ take into consideration all risks

\section{Concentration of ownership}

The term ownership in certain cultures (1384) meaning "human right to object and can make any changes in it except what the law exception" .mnzvr of ownership structure, determine the texture and composition of the shareholders of a company some major owner of the shares of the company. Many economic theorists believe that any type of ownership can also be influential on corporate performance.

Refers to a condition that the remarkable concentration of ownership of company shares to shareholders (majority) belong and shows the percentage shares are in the hands of a few. The results Mahdavi and Mydry (1384) suggests that it was high concentration of ownership in the securities market in 1384 is Tehran. 5 major shareholder in companies active in the market share of the Tehran Stock Exchange, on average, 74\%, and 10 major shareholders of more than $79 \%$, and the share is $20 \%$ shareholder of average $9 / 81$. On the basis of any Fyndal, 
machinery manufacturing industry, and on three other indicators (share 5, 10 and 20 major shareholder) mining industry has the highest concentration of ownership. Mahdavi and Mydry (1384) that compared the indicators of ownership concentration in the market and the five countries of America, Japan, Germany, China, and the Czech Republic indicate that the Iranian stock market is highly concentrated ownership structure. Furthermore, in Iran as well as the Czech state, more focus has been more efficient Ast.bbart smaller property ownership negative impact on performance and therefore the researchers have concluded that due to the lack of protection of minority shareholders, execution plan to transfer ownership of stateowned companies to the public (equity shares) will be reduced to GDP and even unfair income distribution leads Shvd.bvzk and Buzek (2007) reviewed the 244 companies listed on Canadian stock exchange (TSX) concluded that There is an inverse relationship between ownership concentration and performance strategy. Clark and Wojcicki (2005) study found that the concentration of ownership in the firm's German corporate information and stock returns are inversely related. The result of these research results by month Vrpvr quite the opposite in Iran. Vrpvr with 58 samples each month to examine the relationship between concentration of ownership and performance of firms listed in the Tehran Stock Exchange during the period of 1383-1380. He concluded that the concentration of ownership is greater, more control over the actions of managers and improve the company's performance and the relationship between ownership concentration and performance criteria depends on the owner and the factors affecting the performance of Dard.pvlsyry (2005) discussed the effect of the potential lack of focus on the financial health of the company's property. Following this discussion, ding, air and Jvnsky (2004) reviewed the 140 companies listed on the exchange in Beijing, they found a link between concentration of ownership and management, there is no interest in these companies. While state-owned companies and the U-shaped correlation between these two variables (concentration of ownership and earnings management) can be seen. Meanwhile, large state-owned companies are less likely to show profit management. According to the study, Ding and colleagues (2004) as fine as one can guess at a possible link between concentration of ownership and quality of information varies a moderating effect of changing the ownership structure (in terms of the amount of public and private) is there.

\section{BACKGROUND RESEARCH}

In an article introducing Basel III regulations and requirements in the global economy by $\mathrm{M}$. Sepahvand (1393) 2008 financial crisis that brought the intensity and extent of damage is no 
doubt that after the Great Depression, the most important and most difficult crisis that the global economy is going through is. The Basel Committee estimates the cost of this crisis to the global economy close to 100 percent of pre-crisis estimates. Efforts have been made in the area of the roots of the crisis. The report but regardless of the reason the author of this crisis, is seeking to show why the rules and regulations governing the banking system, the frequency and amplitude of the crisis were unable injuries. The introduction of Basel III regulations, which has, in fact, a response to the shortcomings and failures of the regulation. At the end of this article, we summarize existing experience in the international arena looks at the situation and your options on the regulation of the banking system.

The effect of ownership structure of banks in the banking industry of precautionary behavior by $\mathrm{H}$. Kordbache and colleagues (1389) Posted on prudential behavior of banks in the banking industry and its relationship with the particular ownership structure and a set of factors affecting behavior safety in general has been analyzed. With a negative effect on GDP growth due to ownership structure, the size of banks, the ratio of non-performing loans to loans, the State Bank of times the focus and direct relationship with precautionary behavior affects their banks. Accordingly, it can be said that if the management of the banking system to develop more cautious behavior in the banking system are necessary to the structure of the banking system with a higher share of private banks move. It was also noted that the increase in the number of banks and decreasing the concentration of the banking system led to a reduction in precautionary behavior and will increase the risk of banking operations. Therefore, if the goal of the banking system is reducing the risk of banking operations is necessary to balance policies and to avoid focusing on the effect of operational risk applied to banking.

This paper examines the relationship between ownership structure and corporate performance in the Tehran Stock Exchange data panel approach by the doctor Mohammad Nabi Shahiki Tash and colleagues (1391) findings on the basis of both economic value and Tobin's Q model shows a significant and positive relationship and the relationship between institutional ownership and firm performance and firm performance is significant and negative real property. The concentration of ownership, which represents the company's largest shareholder, is the percent share positive and significant relationship with the company.

This paper examines the relationship between financial variables in the banking system's capital adequacy ratio by Doctor Ali Rahmani, Ali Smith (1385) show that the capital adequacy ratio and financial variables than credit risk, size and the ratio of deposits to loans 
Relationship There was a significant inverse. Also, the estimated coefficients, it can be seen that the impact of changes in credit risk of banks' capital adequacy ratio lower than other financial variables.

In this paper, factors affecting capital adequacy ratio of banks by doctor Hamid Sepehrdoust and colleagues (1392) showed that the variables of liquidity and rate of return on assets, a significant positive effect of other factors such as the Bank, the share of credit facilities, rate of return equity, credit facilities and loss reserve leverage, significant negative relationship with their capital adequacy ratio. While there is a significant relationship between the share of deposits and capital adequacy ratio is not approved.

In an article written in Islamic banking capital adequacy purposes doctor David et al. (1387) after studying the theoretical foundations of capital adequacy and discussions related to the nature of Islamic banking and the principles governing it studied using research to by the Islamic Development Bank, Islamic contracts risks, to evaluate the adequacy of capital in both conventional and Islamic banks and has been shown to vary according to the nature of Islamic banking and its corresponding mechanism seems to be revising the Basel Declaration on Islamic banking capital adequacy ratio is necessary.

In a review article on new approaches in banks capital adequacy ratio (according to Basel Banking Regulation and Supervision Committee Statement II) by Masoud Pahlevanzdeh (1386) bank capital adequacy standards, methods, credit risk, market risk, operational and risk banks, the requirements in the assessment of capital adequacy and regulations for disclosure of the relevant procedures, the implementation of the three pillars of the statement of purpose designed. Customer Basel Committee capital raised in the initial statement of risk weighted assets calculation methods developed were flexible as possible. In light of this flexibility, along with the introduction of different approaches for calculating risk assets, the banks choose the best option to achieve the desired minimum standards of Basel Committee, is open. However, the scope of the declaration in areas such as advanced methods for calculating risks it poses, although better coverage of the risks and dangers that threaten a bank led, in part, to the complexity of the statements new.

\section{RESULTS}

The main hypothesis of this study showed that the relationship between ownership concentration and the relationship between ownership concentrations on the capital adequacy of banks is the stability of the capital. 
Following regression model to test hypotheses that:

Bank Risk $i ; t=\beta_{0}+\beta_{1}$ (Ownership Concentration) $i ; t+\beta_{1}\left(\operatorname{Ln}\right.$ (Total Assets) $i ; t+\beta_{2}$ (Leverage) $i ; t_{+} \beta_{3}$ (Revenue Growth) $i ; t_{+} \beta_{4}$ (Loan Loss Provision) $i ; t_{+} \beta_{5}$ ( Tobin' s Q) $i ; t_{+} \beta$ ${ }_{6}\left(\right.$ Equity Volatility) $i ; t_{+} \beta_{7}$ (Deposits) $i ; t_{+} \beta_{8}(\log (\mathrm{GDP})) \mathrm{i} ; \mathrm{t}+\varepsilon_{\mathrm{i} ; \mathrm{t}}$

To test the hypotheses, according to the bank's risk variable as the dependent variable represents the three indicators (capital adequacy, liquidity ratio, the ratio of loans to deposits), the original model to 3 distinct models, so as to focus the effect of bank ownership the three financial indicators is discussed.

\section{Model 1:}

Capital adequacy $=\beta_{0}+\beta_{1}$ (Ownership Concentration) $i ; t+\beta_{1}\left(\operatorname{Ln}\right.$ (Total Assets) $i ; t+\beta_{2}$ (Leverage) $i ; t_{+} \beta_{3}$ (Revenue Growth) $i ; t+\beta_{4}$ (Loan Loss Provision) $i ; t_{+} \beta_{5}$ ( Tobin' s $Q$ ) $i ; t_{+} \beta$ ${ }_{6}\left(\right.$ Equity Volatility) $i ; t_{+} \beta_{7}$ (Deposits) $i ; t_{+} \beta_{8}(\log (G D P)) i ; t+\varepsilon_{i ; t}$

\section{Model 2 :}

Liquidity $=\beta_{0}+\beta_{1}$ (Ownership Concentration) $i ; t+\beta_{1}\left(\operatorname{Ln}\right.$ (Total Assets) $i ; t+\beta_{2}$ (Leverage) $i ; t$ $+\beta_{3}$ (Revenue Growth) $i ; t+\beta_{4}$ (Loan Loss Provision) $i ; t+\beta_{5}$ ( Tobin's Q) $i ; t_{+} \beta_{6}$ (Equity Volatility) $i ; t_{+} \beta_{7}$ (Deposits) $i ; t_{+} \beta_{8}(\log (G D P)) i ; t+\varepsilon_{i ; t}$

\section{Model 3 :}

The ratio of loans to deposits $=\beta_{0}+\beta_{1}$ (Ownership Concentration) $i ; t+\beta_{1}$ (Ln(Total Assets )i; $+\beta_{2}$ (Leverage) $i ; t_{+} \beta_{3}$ (Revenue Growth) $i ; t+\beta_{4}$ (Loan Loss Provision) $i ; t_{+} \beta_{5}$ ( Tobin's Q) $i ; t_{+} \beta_{6}$ (Equity Volatility) $i ; t_{+} \beta_{7}$ (Deposits) $i ; t_{+} \beta_{8}(\log ($ GDP $)) i ; t+\varepsilon_{i ; t}$

Based on the content of speech, the hypotheses are:

$>$ The first main hypothesis: the concentration of ownership and the capital adequacy ratio in banks there is a significant relationship.

$>$ First hypothesis: there is a significant correlation between the concentration of ownership and liquidity in banks

$>$ The second hypothesis: the concentration of ownership and the loans to deposits in banks there is a significant relationship.

The following table results of the model using the software Eviews7 show:

As the results in Table 1 show, P-value calculated for independent variable concentration of ownership (OC), less than the 5\% level and its estimated coefficient is negative variable. As a result, it can be stated that the concentration of ownership of capital adequacy and significant inverse relationship, so that an increase in this variable in the organization, reduced capital adequacy. 
The coefficient of determination of the model is almost 32/0. This number indicates that 32 percent of the dependent variable, can be explained by the independent variables and statistics Because this model is close to Watson camera 2 (94/1), we can say that in this model there is no first order autocorrelation (confirmed by the regression assumptions).

The results in Table 1 show that the p-value of F-test less than 5\% and since, F statistic total funding model shows the result can be said that this model of $95 \%$ is meaningful and credit is high. Thus, according to the results in Table 1, at 95\%, the first hypothesis of this study will be rejected. Also, the control variables, all variables except for variable Tobin's Q, a significant relationship are with variable capital adequacy.

In order to better fit the model, and then remove the control variable Tobin, this model is estimated that the results of this assessment are as follows.

Table 1. Examine the relationship between concentration of ownership on capital adequacy

(Dependent variables: capital adequacy CAR)

\begin{tabular}{|c|c|c|c|c|}
\hline Variable & $\begin{array}{l}\text { Estimated } \\
\text { coefficient }\end{array}$ & SE & T-statistics & P-value \\
\hline Intercept & $44 / 95$ & $3 / 85$ & $11 / 67$ & $0 / 000$ \\
\hline $\begin{array}{l}\text { Concentration } \\
\text { of ownership }\end{array}$ & $-0 / 134$ & $0 / 011$ & $-11 / 46$ & $0 / 000$ \\
\hline Total assets & $-0 / 62$ & $0 / 22$ & $-2 / 75$ & $0 / 000$ \\
\hline $\begin{array}{l}\text { Financial } \\
\text { Leverage }\end{array}$ & $-0 / 35$ & $0 / 046$ & $-7 / 59$ & $0 / 000$ \\
\hline $\begin{array}{l}\text { Revenue } \\
\text { growth }\end{array}$ & $4 / 347$ & $0 / 35$ & $12 / 36$ & $0 / 000$ \\
\hline Loan loss & $1 / 201$ & $0 / 072$ & $16 / 57$ & $0 / 000$ \\
\hline $\begin{array}{l}\text { Volatility of } \\
\text { stock }\end{array}$ & $-0 / 29$ & $0 / 039$ & $-7 / 28$ & $0 / 000$ \\
\hline Deposits & $-1 / 35$ & $0 / 098$ & $-13 / 77$ & $0 / 000$ \\
\hline GDP & $0 / 422$ & $0 / 136$ & $3 / 11$ & $0 / 000$ \\
\hline
\end{tabular}

The coefficient of determination Adjusted coefficient of determination 0/41 


$$
0 / 42
$$

$\begin{array}{lll}\text { Durbin-Watson statistic 1/64 F statistic 293/801 } & \text { Probability of F statistics } \\ & 0 / 000\end{array}$

2 model to examine the relationship between concentration of ownership and liquidity ratio is calculated;

As the results in Table 3 show, P-value (probability statistic F) calculated for independent variable independent ownership concentration (OC), less than the 5\% level and the estimated coefficient of the variable is positive. As a result, it can be stated that the concentration of ownership has a significant correlation with liquidity, so that an increase in this variable in the organization, liquidity increases. The coefficient of determination of the model is almost 28/0. This number indicates that 28 percent of the dependent variable, can be explained by the independent variables and statistics Because this model is close to Watson camera 2 (04/2), we can say that in this model there is no first order autocorrelation (confirmed by the regression assumptions).

The results in Table 3 shows that p-value (probability statistic F) F-test of less than 5\% and since, F statistic total funding model shows the result can be said that this model with $95 \%$ confidence meaningful and the reliability is high. Thus, according to the results in Table 3 , at $95 \%$, the first hypothesis of this study will be accepted. Between control all the variables except Mtghyrnvsanat significant relationship with the dependent variable (liquidity ratio) is.

In order to better fit the model, variable damping control after removing the stock, this model is estimated that the results of this assessment are as follows:

Table 2. Study examines the relationship between concentration of ownership with liquidity (Dependent variable: Liquidity LCR)

\begin{tabular}{lllll}
\hline Variable & $\begin{array}{l}\text { Estimated } \\
\text { coefficient }\end{array}$ & SE & T-statistics & P-value \\
\hline Intercept & $-2 / 19$ & $0 / 29$ & $-7 / 34$ & $0 / 000$ \\
\hline $\begin{array}{l}\text { Concentration } \\
\text { of ownership }\end{array}$ & $0 / 005$ & $0 / 0003$ & $14 / 79$ & $0 / 000$ \\
\hline Total assets & $0 / 038$ & $0 / 008$ & $4 / 36$ & $0 / 000$ \\
\hline Financial & $0 / 037$ & $0 / 003$ & $10 / 74$ & $0 / 000$ \\
\hline
\end{tabular}




\begin{tabular}{lllll}
\hline Leverage & \multicolumn{5}{l}{} \\
\hline $\begin{array}{l}\text { Revenue } \\
\text { growth }\end{array}$ & $0 / 089$ & $0 / 011$ & $7 / 49$ & $0 / 000$ \\
\hline Loan loss & $-0 / 017$ & $0 / 002$ & $-6 / 006$ & $0 / 000$ \\
\hline Tobin, s Q & $1 / 81$ & $0 / 11$ & $16 / 47$ & $0 / 000$ \\
\hline Deposits & $-0 / 03$ & $0 / 004$ & $-8 / 32$ & $0 / 000$ \\
\hline GDP & $0 / 046$ & $0 / 026$ & $3 / 71$ & $0 / 000$ \\
\hline
\end{tabular}

The coefficient of determination Adjusted coefficient of determination 0/277 $0 / 285$

\begin{tabular}{lll}
\hline Durbin-Watson statistic 2/18 & F statistic 102/443 & Probability of F statistics \\
& & $0 / 000$
\end{tabular}

In order to examine the relationship between concentrations of ownership in the ratio of loans to deposits, the third model is estimated.

As the results in Table 5 show, P-value calculated for independent variable concentration of ownership (OC), less than the 5\% level is also the coefficient of this variable is positive, it can be stated that ownership concentration ratio loan to deposit a significant positive relationship . The coefficient of determination of the model is almost 28/0. This number indicates that 28 percent of the dependent variable, can be explained by the independent variables and between $5 / 1$ and $5 / 2$, because this model is Watson statistic camera $(92 / 1)$, we can say that in this model There are no first-order autocorrelation (confirmed by the regression assumptions). Also, the control variables, all variables except Tobin and loans lost a significant relationship with the dependent variable.

The results in Table 5 shows that the p-value of F-test less than $5 \%$ and since, F statistic total funding model shows the result can be said that this model of $95 \%$ is meaningful and credit is high. Thus, according to the results in Table 5, at 95\%, the second hypothesis was not rejected subsidiary of the study. In order to better fit the model, after removing non-significant control variables (loan loss and Tobin's Q), this model is estimated that the results of this assessment are as follows. 
Table 3. Examine the relationship between concentration of ownership in the ratio of loans to deposits

(Dependent variables: capital adequacy CAR)

\begin{tabular}{ccccc}
\hline Variable & $\begin{array}{c}\text { Estimated } \\
\text { coefficient }\end{array}$ & SE & T-statistics & P-value \\
\hline Intercept & $0 / 83$ & $0 / 065$ & $12 / 68$ & $0 / 000$ \\
\hline $\begin{array}{c}\text { Concentration } \\
\text { of ownership }\end{array}$ & $0 / 0005$ & $0 / 0002$ & $2 / 74$ & $0 / 0062$ \\
\hline Total assets & $-0 / 019$ & $0 / 003$ & $-5 / 01$ & $0 / 000$ \\
\hline $\begin{array}{c}\text { Financial } \\
\text { Leverage }\end{array}$ & $0 / 97 / 00$ & $0 / 0007$ & $9 / 801$ & $0 / 000$ \\
\hline Revenue & $-0 / 051$ & $0 / 005$ & $-9 / 62$ & $0 / 000$ \\
\hline growth & $0 / 004$ & $0 / 0006$ & $6 / 39$ & $0 / 000$ \\
\hline Loan loss & $0 / 003$ & $0 / 001$ & $2 / 52$ & $0 / 0119$ \\
\hline Volatility of & & $0 / 001$ & $5 / 933$ & $0 / 000$ \\
\hline stock & $0 / 003$ & $0 / 065$ & $12 / 68$ & $0 / 274$ \\
\hline Deposits & $0 / 83$ & Ad & & \\
\hline GDP & 0 & 0 & & \\
\hline
\end{tabular}

The coefficient of determination Adjusted coefficient of determination 0/274 $0 / 279$

\begin{tabular}{lll}
\hline Durbin-Watson statistic 1/93 F statistic 51/217 & Probability of F statistics \\
& $0 / 000$
\end{tabular}

Results are few control variables, are substantial. First, GDP per capita GDP, which reflects the level of economic development, significant negative coefficient in the model 3 shows. Banks in countries with better economic development, significantly less than the loan as a percentage of their deposits. 
Table 4. Test results of model assumptions

\begin{tabular}{lllll}
\hline Variable & Capital adequacy & Liquidity ratio & $\begin{array}{l}\text { The ratio of loans } \\
\text { to deposits }\end{array}$ \\
\hline $\begin{array}{l}\text { Ownership } \\
\text { Concentration }\end{array}$ & Negative & and & Significant positive & Significant \\
& significant & relationship & positive \\
& relationship. & & relationship \\
\hline
\end{tabular}

\section{CONCLUSION}

However, different scenarios can be equally acceptable where ownership concentration and risk are negatively correlated. In this scenario, large and powerful shareholders may enhance the performance and efficiency in the short term and more specifically, to exert pressure management. It can pressure management initiative to seek new opportunities for venture capital limit (Bvrkart et al., 1977). This point of view is less risk managers and stable capital intensity shareholders when ownership is high, predicts. Here, while the high concentration of ownership aligns the interests of shareholders and managers, but there is no guarantee of better shareholder return. In fact, evidence obtained by Fahlenbrach and Stulz (2011) has pointed to the opposite.. Fahlenbrach and Stulz (2011) state: "There is evidence that banks with CEOs and align incentives with the interests of shareholders, have worse performance and none of them have done better." So, it seems there is already no theoretical position that there is a unique relationship between a concentration of ownership and risk-taking behavior of banks and the consequences of its implementation predict. The analysis of the relationship than an empirical question. In the case of a number of factors specific to the banking and country-specific factors control our actions. As the article Laeven and Levine (2009) is available, the concentration of ownership on the basis of cash flow rights largest shareholder measured.

Table 5. Descriptive statistics of the variables in the research model

\begin{tabular}{|c|c|c|c|c|c|c|c|c|c|}
\hline \multirow[t]{2}{*}{ Variable / statistic } & & & & & & & & & Jarek \\
\hline & Average & Middle & Maximum & Minimum & $\begin{array}{l}\text { Standard } \\
\text { deviation }\end{array}$ & Skewness & Elongation & $\begin{array}{l}\text { Jarek } \\
\text { statistics } \\
\text { for }\end{array}$ & $\begin{array}{l}\text { statistic } \\
\text { is } \\
\text { likely } \\
\text { to }\end{array}$ \\
\hline Capital adequacy & $16 / 87$ & $11 / 48$ & $112 / 18$ & $3 / 82$ & $18 / 71$ & $3 / 60$ & $16 / 82$ & $8097 / 3$ & $0 / 000$ \\
\hline Liquidity & $1 / 01$ & $0 / 96$ & $1 / 70$ & $0 / 86$ & $0 / 22$ & $2 / 58$ & $8 / 56$ & $28 / 79$ & $0 / 000$ \\
\hline
\end{tabular}




\begin{tabular}{|c|c|c|c|c|c|c|c|c|c|}
\hline $\begin{array}{l}\text { The ratio of loans to } \\
\text { deposits }\end{array}$ & $0 / 75$ & $0 / 80$ & $1 / 18$ & $0 / 020$ & $0 / 198$ & $-1 / 11$ & $5 / 56$ & $384 / 99$ & $0 / 000$ \\
\hline $\begin{array}{l}\text { Concentration of } \\
\text { ownership }\end{array}$ & $47 / 03$ & $41 / 48$ & $100 / 00$ & $0 / 00$ & $32 / 53$ & $0 / 06$ & $1 / 53$ & $71 / 77$ & $0 / 062$ \\
\hline Total assets & $18 / 06$ & $18 / 61$ & $21 / 03$ & $13 / 03$ & $2 / 04$ & $-0 / 85$ & $2 / 90$ & $97 / 04$ & $0 / 0563$ \\
\hline Financial Leverage & $11 / 85$ & $9 / 90$ & $42 / 82$ & $0 / 02$ & $9 / 59$ & $1 / 41$ & $5 / 24$ & $433 / 46$ & $0 / 000$ \\
\hline Revenue growth & $-0 / 65$ & $-0 / 70$ & $5 / 18$ & $-2 / 96$ & $1 / 25$ & $2 / 19$ & $11 / 36$ & $2973 / 8$ & $0 / 000$ \\
\hline Loan loss & $7 / 85$ & $5 / 76$ & $32 / 65$ & $1 / 57$ & $6 / 32$ & $1 / 87$ & $6 / 87$ & $76 / 55$ & $0 / 121$ \\
\hline Tvlydnakhals $\neg$ Dakhly & $6 / 82$ & $6 / 85$ & $6 / 97$ & $6 / 67$ & $0 / 106$ & $-0 / 022$ & $1 / 89$ & $3 / 203$ & $0 / 201$ \\
\hline Tobin's Q & $1 / 24$ & $1 / 11$ & $2 / 90$ & $1 / 01$ & $0 / 40$ & $3 / 004$ & $11 / 42$ & $3567 / 2$ & $0 / 000$ \\
\hline Volatility of stock & $24 / 38$ & $25 / 59$ & $51 / 2$ & $7 / 59$ & $9 / 46$ & $0 / 16$ & $3 / 005$ & $3 / 695$ & $0 / 1576$ \\
\hline Deposits & $4 / 31$ & $2 / 34$ & $16 / 63$ & $0 / 020$ & $4 / 32$ & $1 / 25$ & $3 / 59$ & $220 / 25$ & $0 / 000$ \\
\hline number of samples & 16 & 16 & 16 & 16 & 16 & 16 & 16 & 16 & 16 \\
\hline Tdadmshahdat & 64 & 64 & 64 & 64 & 64 & 64 & 64 & 64 & 64 \\
\hline
\end{tabular}

Table 5 shows the summary statistics. The average intensity of an 03/47 (middle 48/41) above Laeven reports and Levine (2009). Thus, the Bank's ownership is more concentrated. The average capital adequacy ratio (CAR) 87/16 (middle 48/11) is. Given that this amount is slightly higher than the average reported by Shehzad and colleagues (2010), it seems that Iranian banks, on average, hold more capital. The average liquidity ratio of 01/1 (Middle 96/0), while the average ratio of loans to deposits 75/0 (Middle 80/0) is.

Leverage ratio as debt divided by equity, average 85/11 (Middle 90/9) is. The average loan loss 8.57 (median 76.5) is lower than the average reported in Laeven and Levine (2009) is. It seems that Iranian banks on average have lower loan loss. Tobin's Q, on average, 24.1 (median 11.1) is. Fluctuations in equity to average 38/24 (mid-59/25) is. Average revenue growth of $65 / 0$ - (median $70 / 0$-) lower than the average growth reported by Laeven and Levine (2009). As the economy is expected to grow rapidly, Iranian banks in the West Bank, a slower growth rate experience. The average deposit of 31.4 (median 34.2) is.

In our study the effect of ownership structure, the size of the bank, the loan to deposit ratio and concentration of direct relationship with precautionary behavior affects banks that parallel research doctor Hamid Kordbacheh and colleagues (1389) is based on the If you can say that the management of the banking system to develop more cautious behavior in the banking system are necessary to the structure of the banking system with a higher share of private 
banks move. It was also noted that the increase in the number of banks and decreasing the concentration of the banking system led to a reduction in precautionary behavior and will increase the risk of banking operations. Therefore, if the goal of the banking system is reducing the risk of banking operations is necessary to balance policies and to avoid focusing on the effect of operational risk applied to banking. The findings about the concentration of ownership, which represents the percent stake in the largest shareholder of the bank is negative and significant relationship with the bank that the evidence obtained by the doctor Mohammad Nabi Shahiki Tash and his colleagues (1391) opposite indicate in the. Then the ratio of capital adequacy and financial variables than credit risk, size and the ratio of deposits to loans is significant inverse relationship. Evidence obtained by Doctor Ali Rahmani and Ali Smith (1385) has pointed to the side of it. Also, the estimated coefficients, it can be seen that the impact of changes in credit risk of banks' capital adequacy ratio than other financial variables. The results showed that the variables of liquidity, loan loss $\neg$ Dakhly GDP and income growth, positive effect and the concentration of ownership variables, total assets, deposits and financial leverage, significant negative relationship with their capital adequacy ratio. While there is a significant relationship between stock volatility and capital adequacy ratio has not been confirmed by the results of research doctor Sepehrdoust H. et al (1392) are in line.

The banks capital adequacy standards, methods, credit risk, market risk, operational and risk banks, the evaluation of capital adequacy requirements and regulations for disclosure of the relevant procedures, the statement by the three pillars of operational objectives designed. Criteria considered in the initial statement Basel Committee capital risk weighted assets calculation methods developed in the field as much as possible, which is more flexible article Pahlevanzdeh M. (1386) was confirmed by Benjamin C. Esty In article 12 June 1997 These findings agree with the hypothesis that strict liability debt, undermines risk-taking commercial banks. These findings, lessons for policies and laws, banks shows that the revenue function of the remaining plaintiffs, a great impact on the institution's management and performance incentives.

In examining relationships between risk, ownership structure and rules, results show that higher ownership concentration increases the risk. Banks in which the property is more focused, more willingness to take risks, show the side of the paper Pichaphop Chalermchatvichien et al. (2014) and also in an article in 2007 is Luc Laeven. 
The relationship between the size of banks and the volatility of bank earnings in the banking industry, our results suggest that larger banks compared with smaller banks have less earnings volatility. As the article Jakob De Haan et al (2011) is available, this inverse relationship in the recent financial crisis even stronger

In relation to corporate governance and performance of banks during the financial crisis seems to banks with stronger corporate governance mechanisms, profits were higher in 1391, as it shows that good governance may have a negative impact on the financial performance of the financial crisis moderate. As the article Sami Vähämaa and colleagues (2009) found results indicate that strong corporate governance practices may have a negative effect on the market value of bank shares have during the crisis, as banks with stronger governance with $\mathrm{Q}$ Toby's and stock returns in the midst of crisis is low. In addition, greater cash flow rights and control via enhanced value products and strong laws to protect shareholders, rate increases and greater cash flow rights, the harmful effects of weak rules to protect shareholder value relieves. With these results in 2007 in line with Article Gerard Caprio and can say, ownership structure, an important mechanism in the banking supervision. By examining board strong, risk-taking banks and the relationship between the board and the risk appetite of banks to the conclusion that there is a strong board of banks (because the board is a reflection of the index shareholders), especially the small board and with less strict a positive impact on the bank's risk appetite. Which is consistent with the findings of Shams Pathan in 2009.

To check that concentrated ownership (under the protection of various levels of equity), subject to administrative control and protection of the rights of shareholders, the Bank's loans have not been implemented significantly reduced. In addition, investors focus on the protection of shareholders, the capital adequacy ratio has a positive effect. At lower levels of protection of shareholders' rights and administrative control, concentration of ownership, reduces the bank's risk appetite, which is consistent with findings in 2010 Choudhry Tanveer Shehzad.

Due to the involvement of the organization, risk-taking behavior of banks depends on the balance of power between management and shareholders. Expected effective governance mechanisms, implement the optimal balance in a manner that ensures alignment of management and shareholder value and to motivate stakeholders to look for opportunities to be risky. According to a variety of human capital, management of incentive to hold down the level of risk. In the range of low levels of ownership concentration in which ownership is low power, low risk and stable investment managers hold up. However, in this range of 
concentration of ownership low, as more property owners and shareholders more power to gain, they manage to accept a higher risk level, are under pressure. So, below a threshold of concentrated ownership, expected capital stability by increasing concentration of ownership goes down, as a result, lead to a negative relationship between the two. However, after a certain threshold concentration of ownership, as ownership concentration increases, the incentives of shareholders to limit risks and maintaining appropriate levels of capital stability altered. So, beyond the threshold, the level of ownership concentration is expected to increase the stability of capital ownership. So, expect a U-shaped relationship between the concentration of ownership and capital stability is acceptable.

\section{REFERENCES}

[1] Shahroki, GH, the Basel Committee, banks and economy magazine, No. 70, page 48 and 49 Khordad 1385.

[2] Hosseini, Ali, is the Basel Committee, the Sun newspaper, 26 Persian dates Shahrivar 1385.

[3] Sabah, Sajjad, Beikmohammadi, 8 compensation familiar with the provisions of the wing 2, a monthly housing bank number 96 of 15/10/1378

[4] Capital adequacy regulations "approved by the Council of Money and Credit thousand fourteenth session dated 11.25.1382.

[5] Safdari, Nfsyh, the status of risk management in banking, newspapers world economy 361 Page 12 Date 13/04/87.

[6] Sadri, Nafisa, position risk in banks, Journal of Accounting and Auditing 1561, page 12 date 04.12.87.

[7] Regulations concerning the capital base of banks and credit institutions "thousand thirteenth session of the Council of Money and Credit Act dated 10.27.1382

[8] Shahroki, G, Basel, 48 and 49 (7) of the banks and the economy.

[9] Attarian, Amir, improving the export competitiveness of small and medium business review magazine February 27 Persian date Esfand 1386.

[10] The world economy - No. 3381 Publication Date: 09/10/1393 doctor M. Bina

[11] Mighty Race, AM, improve transparency in the bank, 1385.

[12] Transparency of bank financial statements to evaluate the necessity of monitoring banks and financial institutions by Dr. Ali Rahmani, S. Hosseini (Spring 91). 
[13] The Role of the financial crisis on key indicators of banks by Dr Peyman Noori et al. (August 1388).

[14]Banking Iran in 1404 (Sunday, Persian date Shahrivar 11 1386)

[15] Basel 3 regulation and its importance in the global economy by M. Sepahvand (May 1, 1393).

[16] The effect of ownership structure of banks in the banking industry of precautionary behavior by H. Kordbache and colleagues (1389).

[17] The relationship between ownership structure and corporate performance in the Tehran Stock Exchange: panel data approach by the doctor Mohammad Nabi Shahiki Tash and colleagues (1391).

[18]Examine the relationship between financial variables in the banking system's capital adequacy ratio by Doctor Ali Rahmani, Ali Smith (1385).

[19]Factors affecting capital adequacy ratio of banks by Doctor Hamid Sepehrdoust and colleagues (1392).

[20] Capital adequacy of Islamic banking doctor Davood Manzoor, et al (1387)

[21] A review of the new approaches in banks capital adequacy ratio (according to Basel Banking Regulation and Supervision Committee Statement II) by Masoud Pahlevanzdeh (1386).

[22] Mahdavi, A.; Mydry, Ahmed al. (1384). Ownership structure and performance of firms in the market in Tehran, Journal of Economic Research, No. 71, Winter 1384, pp. 132-103.

[23] About the bazel committee available at: www. Bis.org.

[24] History of the Bazel committee and its membership, available at: www.bis.org.

[25] Progress on Basel II implementation, availbel at: www.bis.org.

[26] Rose maria Roldun "Basel II -an opportunity for convergence in the Eu, p27-28.

[27] Rosa maria lastva "Risk-based capital vequivements an impact upon the banking indsterg Basel II, 2004, p227.

[28] Basel III, capital stability, risk-taking, ownership: Evidence from Asia Pichaphop Chalermchatvichien, Seksak Jumreornvong, Pornsit Jiraporn, 8 September 2014.

[29] Loan pricing under Basel II in an imperfectly competitive banking market.

[30]David Ruthenberg a,b,*, Yoram Landskroner, 11 July 2008 .

[31]Did good corporate governance improve bank performance DURING THE FINANCIAL crisis? Emilia Peni a,b,*, Sami Vähämaa a,b,** August 2009. 
[32] Bank size, market concentration, and bank earnings volatility in the US, Jakob De Haana,b,c, Tigran Poghosyand,* 4 July 2011.

[33] The Impact of Pillar 3 Disclosure Requirements on Bank Safety Jukka Vauhkonen; 29 April 2011.

[34] The impact of contingent liability on commercial bank risk taking, Benjamin C. Esty; 12 June 1997.

[35] The impact of bank ownership concentration on impaired loans and capital adequacy Choudhry Tanveer Shehzad; 2010.

[36] The credit crisis around the globe: Why did some banks perform better? ) Andrea Beltratti; 2012.

[37] Strong boards, CEO power and bank risk-taking) Shams Pathan; 2009.

[38]A Theory of Bank Regulation and Management Compensation) Kose John; 1998.

[39]Risk Management, Corporate Governance, and Bank Performance during the Financial Crisis) Vincent Aebi; 2010.

[40] Implementing Basel III : Challenges, Options \& Opportunities) Pierre-Etienne Chabanel(

[41] Governance and bank valuation) Gerard Caprio; 2007.

[42]Effects of the New Basel Capital Accord on Bank Capital Requirements for SMEs) EDWARD I. ALTMAN; 2005.

[43]Determinants of bank profitability before and during the crisis: Evidence from Switzerland) Andreas Dietrich; 2011.

[44] Corporate Governance, Regulation, and Bank Risk Taking) Luc Laeven; 2007.

[45] Corporate control, bank risk taking, and the health of the banking industry) Ronald C. Anderson; 1999.

[46] Basel III: Is the cure worse than the disease? ) Bill Allen; 2012.

[47] The option pricing model and the risk factor of stock) dan galai; 1976.

[48]Lee, Shiying, (2005)," Financial Market Development: Does financial liberalization induce regulatory governance reform?" Duke University, Durham, North Carolina.

[49] Shleifer, Andrei, and Robert W. Vishny, (1997), “A Survey of Corporate Governance," The Journal of Finance, Volume 52 (June), pp. 737-83.

[50]Allen, Franklin,\&Xia Gu and Oskar Kowalewski, (2011),"Corporate governance and intra-group transactions in European bank holding companies during the crisis",World Economy Research Institute Warsaw School of Economics (SGH). 
[51]W AI-Chung Lo and Michael C.M.NG, (2009),"Banking reform and corporate Governance",The Chinese Economy, Vol.42, no.5, September- octobr 2009,pp.21-39. 5) Eatwell, John \& Lance Taylor (Polity Press: 2000) Global Finance at Risk THE case for international regulation.

[52] Macey, Jonathan \& Maureen O’ Hara 'Corporate Governance of Banks' Federal Reserve Bank of New York Economic Policy Review 123-141 (April, 2003).

[53]Berger, Allen N. et al (2005), "corporate governance and bank performance: A joint analysis of the static, selection, and dynamic effects of domestic, foreign, and state ownership",Journal of Banking \& Finance 29 (2005) 2179-2221.

[54] Andres, Pablo de \& Eleuterio Vallelado(2008),"Corporate governance in banking: The role of the board of directors", Journal of Banking \& Finance 32(2008) 2570-2580.

[55]Bozec , Y., \& Bozec , R.(2007).Ownership concentration and corporate governance practices: substitution or expropriation effects? Canadian Journal of Administrative Sciences / Revue Canadienne des Sciences de l'Administration, 24 (3), 182 - 195.

[56]Clark \& Worjcik.(2005).Financial Valuation of German Model: The Negative Relationship Between Ownership Concentration and stock ,Market Returns,1997-2001. Economic Geograohy. 81(1), 11-29

[57]Ding, Y., Hua,Y.,\&Junxi,Y.(2004).Ownership concentration and earnings management: A Comparison between Chinese Private and State- Owned Listed companies Retrieved from http://www.commerce.adelaide.edu.au/research.

[58]Ding, Y., Hua,Y.,\&Junxi,Y.(2007). Private vs State Ownership and Earnings Management: Evidence from Chinese Listed Companies. Corporate Governance: An International Review 15(2), 223-238.

[59]Polsiri, P. (2005).Ownership Concentration and Corporate Distress Prediction: A Literature Survey, Retriered from http://www.dpu.ac.th/DPUIC.

\section{How to cite this article:}

Vatanparast M. R and Behtooie H. Relationship between bank ownership concentration on capital adequacy, liquidity, and capital stability in the listed banks in Tehran stock exchange. J. Fundam. Appl. Sci., 2016, 8(3S), 552-570. 